\title{
Censorship in Albania during the dictatorial regime: exclusion of great authors from textbooks of literary history
}

\author{
Brunilda Prifti \\ University of Tirana, Faculty of History and Philology, Department of Literature, Literary \\ Studies, Albania \\ E-mail: brunaprifti@gmail.com
}

\begin{abstract}
As it did with every field of life, the installation of the communist dictatorship in Albania put literature under ideological control, making the path that writers needed to follow mandatory. Whoever opposed it, paid with his/her life, or was punished politically along with his/her work, being excluded from the textbooks of literary history. Important names, such as Gjergj Fishta, Ernest Koliqi, Faik Konica, Zef Skiroi, etc., remained outside of the history of literature throughout the communist period, being mentioned only briefly, along with labels such as "traitor", "collaborationist", "enemy", "collaborator of fascism". Their work did not become part of the study curricula in compulsory or higher education in the country, thus destroying the hierarchy of values and dividing literature into isolated islands that did not communicate with each other. In this paper, we will see how these important figures of Albanian literature were reflected in the two official textbooks of the history of literature $(1959,1983)$ and a text (proof sheets of 1968), which is exactly because it included chapters
\end{abstract}


about the excluded authors, that it was banned from publication after being sent to the printing house.

Keywords: dictatorship, censorship, exclusion, literary history, sentencing, banned writers.

\section{Introduction}

Thirty years after the fall of the harsh dictatorship in Albania, we still do not have a complete, comprehensive history of Albanian literature, one that includes the important names of writers who were convicted with exclusion by the communist regime. Along with their political prosecution, their artistic product and literary works also disappeared, and their channels of communication with the reader were cut off permanently. As a result, entire generations were educated with a mutilated literary history that did not include a large number of important names and had erased along with them the literary currents they represented. This is what happened to Gjergj Fishta, who, from being the "Poet of the Nation", was demoted into being considered a reactionary, a representative of the predatory interests of fascist Italy; the same happened with Faik Konica, the sharp and fearless critic, or Ernest Koliqi, who was branded a collaborationist and traitor, as well as with Arbëresh poet and publicist Zef Skiroi, whose name was only tarnished by the textbooks of literary history written during the dictatorship.

Directly influenced and dictated by the doctrine of the time and written under strict censorship, literary history has made frequent turns over the years, such as erasure of personalities of the literary tradition who gave their name to certain periods of literature, softening of attitudes, attempts at rehabilitation and inclusion, failures, punishments and regressions. We will take a panoramic view, but also delve on a comparative and analytical level into the two official literary history textbooks, that of 1959 and that of 1983, as well as the bold 1968 attempt to include convicted authors, which by its intention to rehabilitate them, ended up condemning itself, since it was not allowed to be published. 


\section{Censorship in Albanian literary history textbooks}

Under the dictatorial regime, literary history had ideological limitations, as did the literary process that flourished at this stage. The restrictions were first reflected in the literary press of the time, shortly after the official boundary line was drawn between the accepted and the excluded tradition (1946). Dhimitër Shuteriqi - writer, former president of the League of Writers and Artists, editor of academic textbooks of Albanian literary history - one of the first-person witnesses to speak about this, specifically mentions the written order to remove several writers from the textbook of literature. "During the academic year 1946, a written order came to remove several writers from the literature textbook. The list included, among others, Gjergj Fishta, Faik Konica, Ernest Koliqi, etc. The perspective at the time could not separate the writer's work from his attitudes" (Papleka, F., 2010).

The order for the banning of the aforementioned authors preceded The Third Conference of the League of Writers and Artists in October 1949, where, among other things, the 'method of socialist realism' was discussed for the first time. "Until 1949, we did not know what socialist realism was. I used to use the term 'social literature", says Shuteriqi (Papleka, F., 2010).

It should be noted that a few days before the conference, a group of members of the Writers' League were called to a meeting at the Political Bureau of the Central Committee of the Albanian Labor Party.

The sentencing of Konica, Fishta and Koliqi, but also the harsh words about Mitrush Kuteli, were accompanied by debate in the meetings of the Writers' League, which were later reflected in the press of the time.

The university textbook that was published in two volumes in 1959 and 1960 is considered to be the first scientific synthesis of the historical path that Albanian literature has traversed from the beginning until today. According to researcher Kujtim Shala, this collective work is the first Albanian literary history with "academic and systematizing ambitions"(Shala, K., 2010)

It was a scrupulous textbook for its time, but which clearly proved the sanctioned ideology for the banned part of literature, which, together with the author, also condemned his work.

Let us make a calculation of figures, concentrating on the names of the authors in focus in our work, which, despite using empirical logic, manage to lead us to a conclusion regarding 
the condemned literary tradition of the time. In this text, the name of Fishta, for whom the ban was officially declared, was mentioned 28 times, Konica's was mentioned 21 times, Skiroi's 20 times and Koliqi's only once. The analysis of works was clearly out of the question.

The boundaries were thus set, and the history of literature did nothing but remain faithfully within them, under censorship. Attempts, in our opinion, not so much with the will to break boundaries, but probably to try to make use of any ray of hope for a little liberty and freedom, met a terrible fate.

$* * *$

Between the textbook of 1959 to that of 1983, multiple reprints were made. The text that marks an exception for the historiography of Albanian literature regarding its most problematic part, 1912 - 1939, from the names that produced literary works at that time, is the one of 1968, even presently found as proof sheets, which the author of this work has consulted at the archive of the Institute of History and Literature in 2012.

"The History of Albanian Literature of the Years 1912-1939", which was not given the right to be published and remains in proof-sheet stage to this day, is a product of the state university of Tirana. The file with the inscription DL-64 (file on literature) bears inventory number 367. The proof sheets reviewed by us are over 322 pages in total, as the last chapter, the one on the 1930s prose writers, starts in page 322. The pages were typed, most of them only on one side.

On the first page of the draft that we are referring to, we find the handwritten note: "It was taken to the press but was suspended". Even now, despite all the attempts to find a reason why this book that had reached so far into the publication process as to have corrections finalized - as confirmed by one of the proofreaders, Klara Kodra - had its publication suspended, we have been unable to. We are also not aware of any written order to suspend the process, just as we could not find the cause for the courage behind this book on literary history, which it would not be an exaggeration to call the most complete among books on literary history as far as the inclusion of authors is concerned.

All the blatant lack of analysis of the works of the authors convicted with exclusion is here remedied by allocating them a decent space.

Most of this space is dedicated to Fishta, who is given a full 48 pages, at the beginning of which, apart from his biography and career, all the works, of all the genres that he explored 
are mentioned. There is also extensive analysis of "Anzat e Parnasit" and "Gomari i Babatasit", "Lahuta e Malcis", his plays and at the end, his art and the importance of his work. This book can be considered the most complete literary history in terms of the inclusion of the authors, and at the same time the most courageous one in terms of trying to rehabilitate the convicted and excluded authors. "Literary historiography of the communist period reached the highest degree of freedom with this book, a degree of freedom that is not evidenced in the 1959-1960 publication, and much less in the 1983 publication" (Sinani, Sh., 2016).

Although there remain many questions that need answers, deductions that require analysis and hypotheses that require documentary support, the work for this book was preceded by a period of considerable constraints. One that cannot be ignored is Plenum IV, 1973, where it was strongly emphasized that it was paramount “to strengthen the party's leadership in literature". Earlier, in 1968, occurred the consolidation and canonization of the educational reform, sealed with Enver Hoxha's dictum "For the further revolutionization of our school" (Hoxha, E., 1969).

$* * *$

The last Albanian literary history textbook used by many generations of pupils, the only one being an official academic production and considered as the goal of scientific synthesis of the results that had been achieved by our literary history studies, is that of 1983 . The work that can be said to have had its way paved by the first attempt made to define the path of historic development of Albanian literature in the two-volume publication of 1959 and 1960, unfortunately turned out to be a regression. As scholar Sabri Hamiti puts it, "This history of Albanian literature with its academic claims, is a chronological order of critical treatment of authors, but on ideological premises"(Hamiti, S., 2010).

The of Albanian history literature from the beginning to the National Liberation War, produced by the Academy of Sciences of the People's Republic of Albania and the Institute of Linguistics and Literature, Tirana, 1983, was produced by an editorial office consisting of: Prof. Vehbi Bala, docent Razi Brahimi, candidate of philological sciences Klara Kodra, docent Ali Xhiku, Dhimitër Fullani, Shaban Çollaku, under the direction of Prof. Dhimitër S.Shuteriqi, and edited by Prof. Dhimitër S.Shuteriqi (editor-in-chief), Prof. Mahir Domi, Dr. Jorgo Bulo, Prof. Vehbi Bala, Docent R. Brahimi. 
At the introduction, in the preface, the editorial office makes it clear that the target audience was higher education, and the relevant curricula on our national literary history had been considered during the production of the textbook, which also aimed at a wider, qualified audience (Akadmia e Shkencave, 1983).

From the contents page, the fate of the banned authors can be clearly understood. The scythe of ideology was now cutting them from the root up, considering that even those few positive statements written in the 1959 edition about their contribution in the field of language, folklore, literary criticism, aesthetic thought, the treatment of new forms, the enriching of Albanian with new foreign words were now either blurred, or set against their life which they had put "at the service" of Fascism, feudal lords, religion, against the people and the poor strata of society.

Their name was the only thing that was mentioned, with an increasing intensity of emphasis of their activity "against the people", and in the best-case scenario, just the titles of their most important works were also referenced. Fishta's name was mentioned 21 times along with the label "academician of fascist Italy", Konica's name 19 times, Skiroi's name 16 times, and the name of Koliqi, "the great traitor" only 2 times.

As researcher Dhurata Shehri points out, "the predominance of context over text distorted even the views on those authors whose works were still in circulation and were still read, taught in schools and not missing from the curricula... But the biggest distortion that this unnatural switching of places brought, was to the general panorama. Context and text speak quite differently"(Shehri, Dh., 2010).

\section{Conclusions:}

The exclusion of some of the greatest Albanian authors from the texts of literary history brought about a distortion of history in itself; the value system was destroyed, and deep gaps were created in the basic knowledge of students of all levels. Through comparisons of three textbooks, two official textbooks $(1959,1983)$, from which all textbooks for lower educational levels were derived, as well as a textbook (1968) abandoned as a collection of proof sheets that never saw the light of publication, we can understand all the tendencies and attempts to reintroduce within the literary system great authors excluded for ideological reasons such as Father Gjergj Fishta, Faik Konica, Ernest Koliqi, and Zef Skiroi, when the 
first order was given, when they were declared "enemies" and how the attitude towards their work has changed.

From what is stated, but also what is left unstated in these texts, it is clear that the ideological criterion was dominant in the evaluation of the works of the authors. It was the state - party that got to decide who would be included and who would stay out of textbooks. And this attitude lasted for nearly half a century.

\section{References}

[1] Akademia e Shkencave e RPS të Shqipërisë (Shuteriqi Dhimitër, Bala Vehbi, Brahimi Razi, Kodra Klara, Xhiku Ali, Xhiku Ali, Fullani Dhimitër, Çollaku Shaban), Historia e Letërsisë Shqiptare: Qё nga Fillimet Deri te Lufta Antifashiste Nacionalçlirimtare. Tirana, 1983.

[2] Akademia e Shkencave të RPSSH and Instituti i Gjuhësisë dhe Letërsisë, Historia e Letërsisë Shqiptare: Që nga Fillimet Deri tek Lufta Nacionalçlirimtare. maketi II, Tirana, 1979.

[3] Akademia e Shkencave, Instituti i Gjuhësisë dhe i Letërsisë, Historia e letërsisë shqiptare e realizmit socialist, Tiranë 1978, Arkivi i Institutit të Gjuhësisë dhe Letërsisë, Tiranë AIGJL

[4] Publication of Shtëpia Botuese e Librit Shkollor, Tirana, 1969.

[5] Konferenca III e Lidhjes së Shkrimtarëve të Shqipërisë. Tirana, 1950.

[6] Papleka, Feride. Dhimitër Shuteriqi. Akademia e Shkencave të Shqipërisë, Tirana, 2010.

[7] Shuteriqi Dh., Bihiku K., Domi M., Bala V., Kodra Z., Sako Z. Historia e Letërsisë Shqipe, Vëllimi I. Universiteti Shtetëror i Tiranës, Tirana, 1959.

[8] Universiteti Shtetëror i Tiranës. Historia e Letërsisë Shqipe e Viteve 1912-1939. proof sheets, Arkiva e Institutit të Letërsisë, Tirana, 1968.

[9] Xhiku, Ali. Sprovë për një Tjetër Histori të Letërsisë Shqipe 1555-1944. Botimet Universitare ALBAS, 2014. 